\title{
PENGARUH REFORMASI BIROKRASI TERHADAP PERIZINAN PENANAMAN MODAL DI DAERAH (Studi Kasus Di Pemerintahan Kota Bekasi)*
}

\author{
Suwari Akhmaddhian \\ E-mail: suwariakhmaddhian@gmail.com
}

\begin{abstract}
Bureaucratic reform is essentially an attempt to reform and fundamental changes to the system of governance in order to reach the goal of bureaucratic reform to accelerate achievement of good governance and efforts to improve support for local government in increasing performance. Bureaucracy reform program runs which is principally consisted of institusional reform, human resources reform and management information technology support in the licensing process. Institutional reform is by estabilishing a new agency that handles the licensing process in the past, licensing process has to go through the different agencies and with the reform of the bureaucracy in the licensing process united in one body that is unified, improve human resources through training and increase the transparency of information through the management information technology support. Bureaucratic reform in investment licensing in the area is already under way in an effort to improve the service to the community, so good governance is not just a dream and soon will become a reality.
\end{abstract}

Key words: licensing, service, bureaucratic reform.

\begin{abstract}
Abstrak
Reformasi birokrasi pada hakikatnya merupakan upaya untuk melakukan pembaharuan dan perubahan mendasar terhadap sistem penyelenggaraan pemerintahaan sehingga tercapai tujuan reformasi birokrasi yaitu untuk memepercepat tercapainya tata kelola pemerintahan yang baik dan upaya memperbaiki dukungan terhadap pemerintah daerah dalam meningkatakan kinerjanya. Program reformasi birokrasi berjalan yang pada pokoknya terdiri dari reformasi kelembagaan, sumber daya manusia dan reformasi manajemen dukungan teknologi informasi dalam proses perizinan. Reformasi kelembagaan yaitu dengan membentuk lembaga baru yang menangani proses perizinan terpadu yang dimasa lalu proses perizinan harus melalui instansi yang berbeda dan dengan adanya reformasi birokrasi proses perizinan di satukan dalam satu badan yang bersifat terpadu, meningkatkan sumberdaya manusia melalui diklat dan meningkatkan keterbukaan informasi melalui manajemen dengan dukungan teknologi informasi. Reformasi birokrasi perizinan penanaman modal di daerah sudah dan sedang berjalan dalam upaya meningkatkan pelayanan terhadap masyarakat sehingga tata kelola pemerintahan yang baik bukan hanya sekedar impian dan segera menjadi kenyataan.
\end{abstract}

Kata kunci: perizinan, pelayanan, reformasi birokrasi.

\section{Pendahuluan}

Pembangunan ekonomi menjadi salah satu jalan dalam mensejahterakan masyarakat, dalam pembangunan ekonomi di perlukan birokrasi yang ramah terhadap penanaman modal. Dalam pembangunan ekonomi terkait erat dengan bergeraknya sektor ekonomi yang men-

- Artikel ini merupakan artikel hasil penelitian mandiri dalam rangka penyusunan tugas akhir perkuliahan (tesis) ciptakan lapangan kerja bagi masyarakat sehingga tujuan Negara dalam memakmurkan rakyatnya tercapai. Penanman Modal yang ada baik yang berasal dari dalam negeri maupun luar negeri mengharapkan proses perizinan penanaman modal yang mereka lakukan berjalan dengan cepat dan murah. Reformasi birokrasi disuarakan mengingat pada masa Orde Baru, birokrasi dijadikan lahan subur untuk praktik kolusi, korupsi, dan nepotisme (KKN). Ketika 
itu, pemerintahan Orde Baru ditopang oleh birokrasi yang rapuh, tidak profesional, dan lebih mengutamakan kepentingan segelintir elite, pengusaha, dan kroni. Soal pelayanan publik atau kepentingan publik, itu nomor sekian. Praktik birokrasi yang korup, inefisien, dan tidak transparan masih sangat terasa hingga saat ini sehingga dampak negatif dari birokrasi model lama masih menghantui dunia usaha. Banyak pihak, terutama kalangan penyelenggara negara, yang tidak menyadari, bahkan mungkin sengaja, memelihara birokrasi yang bisa dimanfaatkan untuk kepentingan sedikit orang. Ukuran keberhasilan reformasi birokrasi adalah jika manfaatnya dirasakan langsung masyarakat sehingga kenyamanan dirasakan. Misalnya saja, jika masyarakat ingin mengurus perizinan masih merasa dipersulit maka reformasi belum berjaIan. Untuk mewujudkan keberhasilan reformasi birokrasi, sebenarnya tidak hanya dari kalangan birokrasi, tetapi juga harus dari luar. Publik harus terus menerus memberikan kritik membangun, menyampaikan aspirasinya, dan berpartisipasi. Dengan adanya reformasi birokrasi diharapkan menjadi tatanan dalam kehidupan masyarakat sehingga dengan adanya tatanan dalam kehidupan masyarakat menjadi serba teratur sehingga tercipta nilai dasar dalam masyarakat yaitu tentang keadilan, kepastian hukum dan kemanfaatan sosial. ${ }^{1}$

Pelayanan publik yang berkualitas menjadi salah satu tolok ukur untuk melihat apakah disuatu organisasi pemerintah (sektor publik) telah terjadi reformasi birokrasi. Masifnya kesan miring yang muncul atas pelayanan publik yang dilakukan oleh sektor publik, tidak terlepas dari kenyataan bahwa rendahnya kualitas pelayanan publik yang diberikan kepada masyarakat sebagai konsumen. Rendahnya pelayanan publik dimaksud, antara lain ditandai dengan beberapa ciri. Pertama, tidak transparannya biaya dalam pengurusan perizinan; kedua, berbelit-belitnya pelayanan bahkan tidak jarang membuat masyarakat menjadi frustasi; dan ke-

Asri M Saleh, "Arti Penting Kehadiran Ombudsman Bagi Masyarakat Di Provinsi Riau", J urnal Hukum Respublica, Vol. 3 No. 2 Tahun 2004, Pekanbaru: FH. Universitas Lancang Kuning. hlm. 228-237 tiga, waktu pelayanan yang tidak jelas, sehingga masyarakat tidak dapat memprediksi kapan selesainya.

Menurut Davidow, pelayanan adalah "service is those thing which when added to a product increase its utility or value to the customer". Pelayanan sendiri adalah hal-hal yang jika diterapkan terhadap suatu produk akan meningkatkain daya atau nilai terhadap pelanggan. Lebih jauh Lovelock (1988) berpendapat bahwa pelayanan yang baik membutuhkan instruktur pelayanan yang sangat baik pula. Hal ini bahwa yang paling penting adalah membuat setiap orang dalam organisasi berkualitas. Kualitas pelayanan sendiri menurut Crosby, Lehtimen dan Wyckoff, merupakan penyesuaian terhadap perincian-perincian (conformance of specification), dimana kualitas ini dipandang sebagai derajat keunggulan yang ingin dicapai, dilakukannya kontrol terus menerus dalam mencapai keunggulan tersebut dalam rangka memenuhi kebutuhan pengguna jasa. ${ }^{2}$ Diharapkan dengan adanya reformasi birokrasi di sektor perizinan penanaman modal berjalan dengan baik sehingga masyarakat yang mengajukan perizinan mendapatkan kemudahan dan secara tidak langsung membantu Negara dalam menciptakan masyarakat yang sejahtera karena mempunyai pekerjaan dan dapat menghidupi keluarganya dengan layak. Pembangunan ekonomi diperlukan dalam upaya mensejahterakan masyarakat melalui penciptaan proyek-proyek baru sehingga menyerap lapangan kerja dan petumbuhan ekonomi.

Tata kelola pemerintahan yang baik atau Good Governance merupakan proses penyelenggaraan birokrasi dalam pelayanan barang dan jasa publik (publik goods and services) yang dalam pelaksanaannya harus senantiasa berpegang pada prinsip-prinsip good governance, yaitu: prinsip efektifitas (effectiveness), keadilan, (equity), partisipasi (participation), akuntabilitas (accountability) dan transparansi (transparency). Kalau kita cermati maka dari

\footnotetext{
Riyadi Soeprapto, Pengembangan Model Citizen Charter Dalam Meningkatkan Pelayanan Publik Di Indonesia, Delegasi, No. 2 Agustus 2005, Banjarmasin: Pusat Penelitian Sekolah Tinggi IImu Admnistrasi, hlm. 123-150
} 
definisi di atas, sebuah tatanan kepemerintahan yang baik senantiasa akan meliputi 3 unsur domain yaitu: negara, swasta dan masyarakat, sehingga good governance mengandung pengertian nilai yang menjunjung tinggi keinginan rakyat, kemandirian, aspek fungsional dan pemerintahan yang efektif dan efisien. UNDP menetapkan karakte-ristik/ prinsip Good Governance sebagai berikut. Pertama, participation: setiap warga negara mempunyai suara dalam pembuatan keputusan; kedua, rule of law: kerangka hukum harus adil terutama hukum HAM; ketiga, tranparency: transparansi/keterbukaan dibangun atas dasar kebebasan arus informasi; keempat, responsiveness: lembaga dan proses harus mencoba untuk melayani setiap pihak yang berkepentingan (stakeholders); kelima, consensus orientation: good governance menjadi perantara kepentingan yang berbeda untuk memperoleh pilihan yang terbaik bagi kepentingan yang lebih luas; keenam, effectiveness and effisiency: proses dan lembaga menghasilkan sesuai dengan apa yang telah digariskan dengan sumber yang tersedia dengan baik; ketujuh, accountability: pembuat keputusan, sektor swasta dan masyarakat bertanggung jawab kepada publik dan lembaga stakeholders; kedelapan, strategic vision: para pemimpin dan publik harus mempunyai perspektif good governance dan pengembangan manusia yang luas serta jauh ke depan. ${ }^{3}$ Organisasi penyelenggara pelayanan publik yang selanjutnya disebut Organisasi Penyelenggara adalah satuan kerja penyelenggara pelayanan publik yang berada di lingkungan institusi penyelenggara negara, korporasi, lembaga independen yang dibentuk berdasarkan undang-undang untuk kegiatan pelayanan publik, dan badan hukum lain yang dibentuk semata-mata untuk kegiatan pelayanan publik. Pelaksana pelayanan publik yang selanjutnya disebut pelaksana adalah pejabat, pegawai, petugas, dan setiap orang yang bekerja di dalam organisasi penyelenggara yang bertugas

Ade Suhendar, "Keterbukaan Informasi Publik Bentuk Keseriusan Pemerintah Menuju Good Governance (Implementasi Undang Undang Nomor 14 Tahun 2008)", J urnal Wacana Kerja, Vol. 13 No.2 November 2010, Bandung: Pusat Kajian dan Pendidikan dan Penelitian Aparatur, hlm. 243-251 melaksanakan tindakan atau serangkaian tindakan pelayanan publik. Masyarakat adalah seluruh pihak, baik warga negara maupun penduduk sebagai orang perseorangan, kelompok, maupun badan hukum yang berkedudukan sebagai penerima manfaat pelayanan publik, baik secara langsung maupun tidak langsung. Standar pelayanan adalah tolok ukur yang dipergunakan sebagai pedoman penyelenggaraan pelayanan dan acuan penilaian kualitas pelayanan sebagai kewajiban dan janji penyelenggara kepada masyarakat dalam rangka pelayanan yang berkualitas dan dilengkapi dengan asas-asas, norma-norma sehingga pelayanan menjadi cepat, mudah, terjangkau, terukur dan transaparan agar fungsi mereka sesuai dengan yang digariskan. ${ }^{4}$ Reformasi birokrasi pada pelayanan publik mutlak harus berjalan karena reformasi birokrasi pintu masuk menuju pemerintahan baik yang sehat dan berkeadilan. Prinsip dan mekanisme pelayanan. Dalam kerangka good governance maka prinsip pelayanan publik mencakup: efektifitas dan efisiensi; demokrasi; transparansi; taat hukum; menghargai HAM; responsive; representative; dan akuntabel. ${ }^{5}$

Maklumat pelayanan adalah pernyataan tertulis yang berisi keseluruhan rincian kewajiban dan janji yang terdapat dalam standar pelayanan. Sistem informasi pelayanan publik yang selanjutnya disebut Sistem Informasi adalah rangkaian kegiatan yang meliputi penyimpanan dan pengelolaan informasi serta mekanisme penyampaian informasi dari penyelenggara kepada masyarakat dan sebaliknya dalam bentuk lisan, tulisan Latin, tulisan dalam huruf Braile, bahasa gambar, dan/atau bahasa lokal, serta disajikan secara manual ataupun elektronik. Mediasi adalah penyelesaian sengketa pelayanan publik antarpara pihak melalui bantuan, baik oleh ombudsman sendiri maupun melalui mediator yang dibentuk oleh ombudsman. Ajudikasi adalah proses penyelesaian sengketa pelayanan publik antar para pihak yang diputus 0-

Jawahir Thontowi, "Norma Hukum Pelayanan Publik", J urnal Hukum, Vol. 14 No.3 April 2004, Yogyakarta: FH Universitas Islam Indonesia, hlm. 435-449

Zaidan Nawawi, "Kinerja Pelayanan Publik", Jurnal Eksekutif, Vol. 4 No. 2 Agustus 2007, Surabaya: Sekolah Tinggi Ilmu Ekonomi IBMT, hlm. 257-262 
leh ombudsman. Ombudsman adalah lembaga negara yang mempunyai kewenangan mengawasi penyelenggaraan pelayanan publik, baik yang diselenggarakan oleh penyelenggara negara dan pemerintahan termasuk yang diselenggarakan oleh badan usaha milik negara, badan usaha milik daerah, dan badan hukum milik negara serta badan swasta, maupun perseorangan yang diberi tugas menyelenggarakan pelayanan publik tertentu yang sebagian atau seluruh dananya bersumber dari anggaran pendapatan dan belanja Negara dan/atau anggaran pendapatan dan belanja daerah. Masyarakat memiliki hak untuk melakukan pengawasan karena penyelenggaraan pemerintahan dan penyelenggaraan Negara adalah mandat yang di berikan rakyat melalui pemilihan umum sehingga rakyat dapat memperoleh pelayanan publik yang baik. ${ }^{6}$ Ombudsman adalah badan atau petugas independen yang bertugas menampung keluhan-keluhan masyarakat tentang perilaku pegawai negeri yang tidak benar seperti penyalahgunaan wewenang, kelambatan penyelesaian tugas, dan lainnya. Bidang kerja ombudsman juga berhubungan dengan masalah-masalah perlindungan konsumen, hak sipil, perpajakan, lingkungan, lembaga pemasyarakatan, dan sebagainya. Lembaga ini kemudian meneliti, melaporkan, mengusulkan pemecahan masalahnya kepada pemerintah. Secara yuridis lembaga ombudsman tidak, mempunyai wewenang kekuasaan, namun dengan keritikan, teguran dan publisitas, maka diharapkan dapat mempengaruhi pemerintah dalam menjalankan tugas-tugas pemerintahan secara baik. ${ }^{7}$ UU No. 25 Tahun 2009 tentang Pelayanan Publik dimaksudkan untuk memberikan kepastian hukum dalam hubungan antara masyarakat dan Penyelenggara dalam pelayanan publik, yang mempunyai tujuan: terwujudnya batasan dan hubungan yang jelas tentang hak, tanggung jawab, kewajiban, dan kewenangan seluruh pihak yang terkait dengan penyelenggaran pelayanan publik; terwujudnya sistem penyelenggaraan pelayanan

\footnotetext{
6 Asmara Budi Dyah Dharma Sutji, "Ombudsman di Indonesia", Jurnal Hukum dan Masyarakat, Vol. 33 No. 1 2008, hlm. 67-68

7 Asri M Saleh, op.cit, hlm. 228-237
}

publik yang layak sesuai dengan asas-asas umum pemerintahan dan korporasi yang baik; terpenuhinya penyelenggaraan pelayanan publik sesuai dengan peraturan perundang-undangan; dan terwujudnya perlindungan dan kepastian hukum bagi masyarakat dalam penyelenggaraan pelayanan publik. Dalam Undang-undang No. 25 Tahun 2009 tentang Pelayanan Publik Pasal 4 menyatakan bahwa penyelenggaraan pelayanan publik berasaskan yaitu: kepentingan umum; kepastian hukum; kesamaan hak; keseimbangan hak dan kewajiban; keprofesionalan; partisipatif; persamaan perlakuan/tidak diskriminatif; keterbukaan; akuntabilitas; fasilitas dan perlakuan khusus bagi kelompok rentan; ketepatan waktu; dan kecepatan, kemudahan, dan keterjangkauan.

\section{Permasalahan}

Pokok permasalahan yang menjadi fokus perhatian utama yang akan dibahas dalam penelitian ini dapat di uraikan dalam pertanyaan. Pertama, mengapa terjadi hambatan di sektor perizinan penanaman modal di daerah, sebelum reformasi birokrasi? Kedua, bagaimana implementasi reformasi birokrasi di sektor perizinan penanaman modal di daerah? Ketiga, apakah manfaat reformasi birokrasi di sektor perizinan penanaman modal di daerah bagi masyarakat?

\section{Metode Penelitian}

Metode penelitian yang digunakan oleh penyusun dalam pembahasan penelitian ini adalah metode evaluatif analisis, yaitu suatu metode mengumpulkan dan menyajikan data yang diperoleh untuk menganalisis keadaan yang sebenarnya dan selanjutnya dilakukan analisa rasional berdasarkan acuan yuridis melalui penelitian kepustakaan dan penelitian lapangan. Studi Kepustakaan yaitu mencari dan menggunakan sumber dari data primer berupa jurnal ilmiah, peraturan perundang-undangan, buku-buku, internet, artikel, diktat kuliah dan tulisan lain yang ada hubungannya dengan materi penulisan hukum. Studi lapangan yaitu melakukan observasi ke instansi yang menjadi objek penelitian yaitu Badan Pelayanan Perizinan Terpadu, serta melakukan wawancara 
dengan pengusaha, pengurus APINDO, pengelola perusahaan, akademisi dan praktisi hukum. Pengolahan dan Analisis Data. Setelah data terhimpun, maka dilakukan pengolahan dan analisis data secara kualitatif sehingga menghasilkan sesuai harapan.

\section{Pembahasan}

\section{Tinjauan Umum tentang Reformasi Birokrasi}

Reformasi birokrasi merupakan tuntutan era reformasi yang mulai digulirkan pada tahun 1998 untuk memperbaiki pelayanan negara terhadap warganya. Kata reformasi berasal dari istilah latin yaitu formare yang artinya membentuk berasal dari kata forma yang artinya membentuk. Sesuai dengan kata asalnya maka istilah reformasi mempunyai beberapa pengertian. Pertama, suatu perubahan kearah yang lebih baik atau suatu peningkatan; kedua, koreksi dari kesalahan, penyimpangan, atau pelanggaran; ketiga, suatu tindakan untuk revolusioner. Sebagai istilah yang dipergunakan berkaitan dengan pemerintah atau Negara, maka istilah reformasi dapat berarti menempatkan suatu bentuk atau kondisi yang baru dan peningkatan; untuk memperbaiki bentuk negara, atau membawa perubahan dari yang buruk kepada yang baik sehingga kesejahteraan sebagai tujuan dapat tercapai. ${ }^{8}$ Pendapat yang lain mengatakan bahwa reformasi berarti perubahan dengan melihat keperluan masa depan, menekankan kembali pada bentuk asal, berbuat lebih baik dengan menghentikan penyimpangan-penyimpangan dan praktek yang salah atau memperkenalkan prosedur yang lebih baik. Suatu perombakan menyeluruh dari suatu system kehidupan dalam aspek politik, ekonomi, hukum dan sosial. Reformasi juga berarti memperbaiki, membetulkan, menyempurnakan dengan membuat sesuatu yang salah menjadi benar. Oleh karena itu, reformasi berimplikasi untuk mengubah sesuatu dan menghilangkan yang tidak sempurna menjadi lebih sempurna, misalnya melalui perubahan kebijakan institusional. Dengan demikian dapat dikemukakan karena karakteristik reformasi dalam bidang tertentu,

8 Yefni Delfitri, 2005, Reformasi Birokrasi di Mahkamah Agung, J akarta: Universitas Krisnadwipayana, hlm. 27 yaitu: pertama, adanya keadaan yang tidak memuaskan pada masa lalu; kedua, keinginan untuk memperbaiki pada masa yang akan datang; ketiga, adanya perubahan besar-besaran; keempat, adanya orang yang melakukan; kelima, adanya pemikiran atau ide-ide baru; dan keenam, adanya sistem dalam suatu institusi tertentu tidak baik dalam skala kecil maupun skala besar seperti pada institusi Negara. ${ }^{9}$

Reformasi secara umum berarti perubahan terhadap suatu sistem yang telah ada pada suatu masa. Kendati demikian, kata reformasi sendiri pertama-tama muncul dari gerakan pembaruan di kalangan Gereja Kristen di Eropa Barat pada abad ke-16, yang dipimpin oleh Martin Luther, Ulrich Zwingli dan Yohanes Calvin. Reformasi adalah proses penataan ulang, mengubah, memperbaiki, dan menyempurnakan sesuatu agar menjadi lebih baik. Berdasarkan pengertian-pengertian diatas, maka reformasi selalu menyesuaikan diri dengan kondisi dan kebutuhan masyarakat saat ini, bahkan sebisa mungkin dapat juga memenuhi kebutuhan masyarakat dimasa depan. Oleh karena itu, reformasi merupakan gerakan yang berlangsung terus menerus dan tidak akan berakhir. Perubahan yang dijalankan dalam rangka reformasi tetap berpijak pada nilai-nilai dasar falsafah Negara yang sudah ada, tetapi dengan cara memperbaiki atau menyempurnakan langkahlangkah yang tidak benar. Birokrasi dewasa ini masyarakat begitu peka dengan istilah tersebut. Hampir semua lapisan masyarakat mengenal sebutan birokrasi, terutama di kalangan orang berpendidikan. Hal yang terdeteksi dalam pandangan mereka, birokrasi adalah urusan-urusan yang menjengkelkan, berbelit-belit, be-rantai, aturan ketat dan banyak sekat-sekat formalitas. Padahal birokrasi itu sendiri secara epistemologis berasal dari bahasa yunani: "Bureau", yang artinya "meja tulis atau tempat bekerja para pejabat". sesungguhnya birokrasi itu merupakan sarana bagi pemerintah yang berkuasa untuk melaksanakan pelayanan publik sesuai dengan aspirasi masyarakat. Birokrasi adalah "tipe dari suatu organisasi yang dimaksud-

\footnotetext{
Yefni Delfitri, op.cit, hlm. 29-30.
} 
kan untuk mencapai tugas-tugas administratif yang besar dengan cara mengkoordinasi secara sistematis (teratur) pekerjaan dari banyak orang". ${ }^{10}$ Reformasi yang terjadi mempunyai makna positif yang menandai adanya keinginan bebenah dan berubah menuju sesuatu yang lebih baik. Sementara itu birokrasi dimaknai sebagai keseluhuran organisasi pemerintah yang menjalankan tugas-tugas Negara dalam berbagai unit organisasi pemerintah dan lembaga non departemen baik di pusat maupun di daerah. Dengan demikian, reformasi birokrasi dimaknai sebagai usaha yang menjadi suatu adanya keinginan untuk merubah atau membenahi suatu organisasi pemerintah yang menjalankan tugastugas negara dalam hal ini pelayanan publik untuk menjadi sesuatu yang lebih baik. ${ }^{11}$

\section{Penanaman Modal}

Izin adalah persetujuan dari penguasa berdasarkan Undang-Undang atau peraturan Pemerintah untuk dalam keadaan tertentu menyimpang dari larangan umum tersebut. Izin adalah instrumen pemerintah dalam rangka menyelenggarakan pemerintahan dalam mengatur kepentingan umum. Izin adalah seperangkat peraturan yang berisi tentang perkenaan atau izin. Wewenang lahir karena adanya UU/hukum yang tertulis. Norma ialah isi dari hukum yaitu yang terdiri dari tiga hal: norma perintah misalnya dalam hal pajak, norma larangan misalnya dalam Pasal KUHP, dan norma membolehkan misalnya dalam KUHPerdata. Kekuasaan merupakan hak Jabatan, yang berbeda dengan Kewenangan yang merupakan hak yang dijalankan karena adanya tanggung jawab. Izin dalam istilah asing (Belanda) disebut Verguming. Bentuk Izin itu harus tertulis. HO (Hinder Ordonantie) yaitu sebuah izin yang diberikan oleh masyarakat sekitar untuk usaha yang ada disitu.

10 Jailani, “Urgensi Nilai-Nilai Akhlaq pada Birokrasi Pemerintahan dalam Pelayanan Publik", Al-Bayan, Vol. 12 No. 13, J anuari -J uni 2006, Nanggroe Aceh Darussalam: Fakultas Dakwah Institut Agama Islam Negri Ar-Rainy. hlm. 81-96

11 Denok Kurniasih dan Anwaruddin, "Reformasi Birokrasi Pelayanan Perizinan di Kabupaten Banyumas (Studi di Kantor Pelayanan Perizinan dan Investasi)", J urnal Humanis, Vol. I No. 2 Nopember 2007 - April 2008, hlm. $72-79$
Izin adalah suatu keputusan administratif negara yang memeperkenankan sesuatu perbuatan yang pada umumnya dilarang, tetapi dapat diperkenankan dan bersifat konkrit. Izin mempunyai sifat mengendalikan suatu kegiatan atau perilaku individu atau kolektivitas yang sifatnya preventif seperti dispensasi, izin dan konsesi. Dispensi adalah keputusan administrasi yang membebaskan suatu perbuatan dan kekuasaan suatu peraturan yang menolak perbutan itu. Konsesi adalah suatu perbutan yang penting bagi umum, tetapi pihak swasta dapat turut serta dengan syarat pemerintah ikut campur. ${ }^{12}$

Menurut Syachran Basah memberikan pengertian mengenai izin adalah perbuatan hukum administrasi negara bersegi satu yang menghasilkan peraturan dalam hal kontrol berdasarkan persyaratan dan prosedur sebagaimana ditetapkan oleh ketentuan perundangun-undangan yang berlaku. Menurut Ahmad Sobana mekanisme perizinan dan izin yang ditertibkan untuk pengendalian dan pengawasan administratif bisa digunakan sebagai alat untuk mengevaluasi keadaan dan tahapan perkembangan yang ingin dicapai, disamping untuk mengendalikan arah perubahan dan mengevaluasi keadaan, potensi serta kendala yang disentuh untuk berubah. ${ }^{13}$ Pengertian izin adalah suatu persetujuan penguasa untuk dalam keadaan tertentu menyimpang dari ketentuan-ketentuan larangan peraturan perundang-undangan yaitu: dispensasi adalah keputusan pejabat pemerintah yang bebas suatu perbuatan dari kekuasaan peraturan yang menolak perbuatan tersebut, Lisensi adalah izin untuk menyelenggarakan perusahaan, Konsesi adalah suatu izin yang berhubungan besar dimana kepentingan umum di mana sebenarnya ada tugas pemerintah tetapi pemerintah memberikan hak kepada konsesi yang bukan pejabat pemerintah.

Izin dalam arti luas adalah suatu persetujuan dari penguasa berdasarkan undang-undang atau peraturan dalam keadaan tertentu menyimpang dari larangan ketentuan peraturan perundang-undangan dan hal ini menyangkut 12 Nomensen Sinamo, 2010, Hukum Administrasi Negara,
Jakarta: PT. Jala Permata Aksara, hlm. 77

$13 \mathrm{lbid}, \mathrm{hlm} .79$. 
tindakan demi kepentingan umum. Izin dalam arti sempit yaitu pembebasan, dispensasi, konsesi. Izin dalam arti sempit adalah izin yang pada umumnya didasarkan pada keinginan pembuat Undang-Undang untuk mencapai suatu tatanan tertentu atau menghalangi keadaan-keadaan buruk, seperti pembebasan/dispensasi adalah pengecualian atas larangan sebagai aturan umum yang berhubungan erat dengan keadaan-keadaan khusus. Konsesi adalah izin yang berkaitan dengan usaha diperuntukkan untuk kepentingan umum. Menurut Prajudi Atmosudirdjo yang dikuti Philipus M. Hadjon menerangkan bahwa izin (vergunning) adalah dispensasi dari suatu larangan. Hal ini berarti bahwa dalam keadaan tertentu suatu ketentuan hukum dinyatakan tidak berlaku untuk hal tertentu yang ditetapkan dalam suatu keputusan tata usaha negara. ${ }^{14}$

Sistem perizinan diharapkan mencapai tujuan tertentu diantaranya yaitu adanya suatu kepastian hukum, perlindungan kepentingan umum, pencegahan keruksakan atau pencemaran lingkungan dan pemeratan distribisi barangbarang tertentu. Macam-macam sanksi dalam hukum administrasi negara hukum perizinan merupakan bagian dari hukum administrasi. Untuk itu terhadap hukum perizinan akan diterapkan pula sanksi administrasi. Macam sanksi dalam hukum administrasi adalah sebagai berikut: ${ }^{15}$ pertama, paksaan pemerintah (Bestuurdwang); kedua, penarikan kembali keputusan. Keputusan akan ditarik kembali oleh Pemerintah, apabila: yang berkepentingan tidak mematuhi pembatasan pembatasan, syarat-syarat, atau ketentuan peraturan perundang-undangan; dan yang berkepentingan pada waktu mengajukan permohonan menggunakan data yang tidak benar atau tidak lengkap. Ketiga, pengenaan denda administratif; dan keempat, pengenaan uang paksa.

14 Helmi, "Membangun Sistem Perizinan Terpadu Bidang Lingkugan Hidup Di Indonesia", J urnal Dinamika Hukum, Vol. 11 No.1 Januari 2011. Purwokerto: FH UNSOED, hlm. 134-142

15 Elita Rahmi, "Perizinan Dalam Pemerintahan (Sebuah Tantangan dan Harapan di Era Otonomi)", J urnal Hukum Respublica, Vol. 4 No. 1 Tahun 2004, Pekanbaru: FH Universitas Lancang Kuning, hlm. 122-130
Penanaman modal menurut UU No. 25 Tahun 2007 tentang Penanaman Modal Pasal 1 Ayat (5) adalah penggunaan daripada kekayaan masyarakat Indonesia dan atau asing, termasuk hak-hak dan benda-benda, baik yang dimiliki oleh negara maupun swasta nasional atau swasta asing yang berdomisili di Indonesia, yang disisihkan/disediakan guna menjalankan sesuatu usaha. Penanaman Modal adalah segala bentuk kegiatan menanam modal, baik oleh penanam modal dalam negeri maupun penanam modal asing, untuk melakukan usaha di wilayah negara Republik Indonesia. Penanaman Modal Asing adalah kegiatan menanam modal untuk melakukan usaha di wilayah negara Republik Indonesia yang dilakukan oleh penanam modal asing, baik yang menggunakan modal asing sepenuhnya maupun yang berpatungan dengan penanam modal dalam negeri. Penanaman modal dalah perseorangan atau badan usaha yang melakukan Penanaman Modal yang dapat berupa penanam modal dalam negeri dan penanam modal asing. Di negara-negara berkembang di antaranya Indonesia, bantuan luar negeri secara langsung berdampak positif terhadap tabungan domestik, yaitu memberikan indikasi adanya kenaikan proporsi tabungan dari golongan masyarakat yang memperoleh kenaikan pendapatan.

Menurut Wibawa, pelayanan publik sektor ekonomi memiliki berbagai aspek. Pertama, mengenai prinsip-prinsip pelayanan ekonomi yang menerapkan kesederhanaan, kejelasan, kepastian, dan ketepatan waktu, tidak diskriminatif, bertanggung jawab, kemudahan akses, kejujuran, kecermatan, kedisiplinan, kesopanan, keramahan, dan kenyamanan. Kedua, penyelenggara pelayanan ekonomi, dalam hal ini pemerintah (pusat maupun daerah), perlu menyusun dan menetapkan standar, antara lain meliputi persyaratan prosedur pelayanan, waktu penyelesaian, biaya pelayanan, kompetensi petugas, pengawasan intern, penanganan pengaduan saran/masukan, dan jaminan pelayanan. Penyelenggaraan pelayanan ekonomi juga harus menyelenggarakan penilaian kinerjanya melalui survey indeks kepuasan masyarakat secara periodik. Ketiga, pentingnya ruang-ruang 
publik sebagai akses masyarakat jika pelayanan ekonomi tidak memuaskan. Jika penyelenggara pelayanan ekonomi tidak memuaskan, masyarakat dapat mengajukan klaim, menggugat ke meja hijau. ${ }^{16}$

\section{Implementasi Reformasi Birokrasi Perizinan di Kota Bekasi.}

Kota Bekasi merupakan salah satu kota yang terdapat di provinsi Jawa Barat, Indonesia. Kota ini berada dalam lingkungan megapolitan Jabodetabek dan menjadi kota besar keempat di Indonesia yang memiliki peran multifungsi yaitu lokasi industri, perumahan dan sentra perdagangan. Saat ini kota Bekasi berkembang menjadi kawasan sentra industri dan kawasan tempat tinggal kaum urban. Secara geografis kota Bekasi berada pada ketinggian $19 \mathrm{~m}$ diatas permukaan laut. Kota ini terletak di sebelah timur Jakarta; berbatasan dengan Jakarta Timur di barat, kabupaten Bekasi di utara dan timur, kabupaten Bogor di selatan, serta kota Depok di sebelah barat daya. Dari total luas wilayahnya, lebih dari $50 \%$ sudah menjadi kawasan efektif perkotaan dengan $90 \%$ telah menjadi kawasan perumahan, $4 \%$ telah menjadi kawasan industri, $3 \%$ telah digunakan untuk perdagangan, dan sisanya untuk bangunan lainnya. Kota ini sebelumnya merupakan sebuah kecamatan dari kabupaten Bekasi yang kemudian berkembang dan ditingkatkan statusnya pada tahun 1982 menjadi kota administratif Bekasi yang saat itu terdiri atas empat kecamatan yaitu kecamatan Bekasi Timur, Bekasi Selatan, Bekasi Barat, dan Bekasi Utara, dan meliputi 18 kelurahan serta 8 desa. Di tahun 1996 kota administratif Bekasi kembali ditingkatkan statusnya menjadi kotamadya (sekarang kota). Berdasarkan hasil pencacahan Sensus Penduduk 2010. Jumlah Penduduk Kota Bekasi angka sementara adalah 2.336.498 orang.

Birokrasi perizinan penanaman modal merupakan tulang punggung dalam pelayanan publik, pelayanan publik yang baik harus efektif,

16 T. Nazarudin Sulaiman, "Landasan Teoritik Pelayanan Perizinan Terpadu Satu Pintu", Suloh: J urnal Penelitian dan Pengkajian Hukum, Vol. 6 No. Edisi Khusus 2008, hlm. 1-26 efesien dan murah. Sebelum reformasi birokrasi terjadi ada hambatan-hambatan seperti perizinan penanaman modal di daerah sebelum adanya reformasi birokrasi tersebar dalam beberapa dinas dan badan di daerah antara lain : Surat Izin Usaha Perdagangan (SIUP), Tanda Daftar Perusahaan (TDP), Surat Izin Usaha Industri (SIUI), Tanda Daftar Gudang (TDG) instansi yang mengeluarkan adalah Dinas Perindustrian dan Perdagangan Kota Bekasi, Surat Izin Usaha J asa Konstruksi (SIUJ K) instansi yang mengeluarkan adalah Dinas Bina Marga di Kota Bekasi, Izin Mendirikan Bangunan (IMB) instansi yang mengeluarkan adalah Dinas Tata Ruang dan Bangunan Kota Bekasi, Izin Pelayanan Kesehatan seperti Izin Apotek, Izin Toko Obat, Izin Praktek Dokter, Izin Praktek Bidan dan Izin Sarana Pelayanan Kesehatan instansi yang mengeluarkan adalah Dinas Kesehatan Kota Bekasi, Izin Analisis Dampak Lingkungan (AMDAL) instansi yang mengeluarkan adalah Badan Lingkungan Hidup Daerah Kota Bekasi, Izin Pertambangan Galian C dan Izin Penggambilan Air Bawah Tanah instansi yang mengeluarkan izin adalah Dinas Sumber Daya Alam dan Pertambangan Kota Bekasi, Izin Trayek dan Pengusaha Angkutan instansi yang mengeluarkan izin adaIah Dinas Perhubungan Kota Bekasi, Surat Izin Usaha Pariwisata (SIUP) instansi yang mengeluarkan adalah Dinas Kebudayaan dan Pariwisata Kota Bekasi.

Birokasi perizinan merupakan salah satu permasalahan yang menjadi kendala bagi perkembangan usaha di Indonesia. Kondisi pelayanan perizinan saat ini masih dihadapkan pada sistem yang belum efektif dan efisien serta belum sesuai dengan tuntutan masyarakat. Hal ini dapat dilihat dari banyaknya pengaduan dan keluhan dari masyarakat baik secara langsung maupun tidak langsung mengenai kinerja aparatur dan banyaknya peraturan yang tumpang tindih, prosedur yang berbelit-belit, tidak ada kepastian jangka waktu penyelesaian, tingginya biaya yang harus dikeluarkan, banyaknya persyaratan yang harus dipenuhi, sikap petugas yang kurang responsive, sarana yang kurang menunjang dan lain-lain, sehingga menimbulkan citra yang kurang baik terhadap kinerja Pe- 
merintah Daerah. Untuk mengatasi kondisi tersebut perlu dilakukan upaya perbaikan kualitas berkesinambungan demi mewujudkan pelayanan publik yang prima. Upaya perbaikan kualitas pelayanan perizinan dilakukan melalui serangkaian regulasi kebijakan sebagai wujud reformasi birokrasi pelayanan publik yang telah dicanangkan oleh Pemerintah kota Bekasi.

Badan Pelayanan Perizinan Terpadu (BPPT) Kota Bekasi yang merupakan badan pelayanan investasi sesuai dengan amanat Peraturan perundang-undangan yaitu adalah dibentuk berdasarkan peraturan Perundang-undangan yaitu : Undang-Undang Nomor 25 Tahun 2007 tentang Penanaman Modal, Peraturan Pemerintah Nomor 38 Tahun 2007 antara Pemerintah, Pemerintahan Daerah Provinsi, dan Pemerintahan Daerah Kabupaten/Kota, Peraturan Pemerintahan Nomor 41 Tahun 2007 tentang Organisasi Perangkat Daerah, Instruksi Presiden Nomor 3 Tahun 2006 tentang Paket Kebijakan Perbaikan Iklim Investasi, Peraturan Menteri Dalam Negeri Nomor 24 Tahun 2006 tentang Pedoman Penyelenggaraan Pelayanan Satu Pintu, Peraturan Daerah Kota Bekasi Nomor 09 Tahun 2008 tentang Pembentukan Badan Pelayanan Perizinan Terpadu Kota Bekasi

Pembentukan Badan Pelayanan Perizinan Terpadu (BPPT) Kota Bekasi berdasarkan Peraturan Daerah No. 09 Tahun 2008 pada dasarnya ditujukan untuk menyederhanakan birokrasi perizinan dalam bentuk; pemangkasan tahapan dan prosedur, baik prosedur lintas instansi mau pun didalam instansi yang bersangkutan; pemangkasan biaya; pengurangan jumlah persyaratan; pengurangan jumlah paraf dan tanda tangan yang diperlukan; pengurangan waktu rata-rata pemrosesan perizinan. Badan Pelayanan Perizinan Terpadu Kota Bekasi mempunyai struktur organisasi untuk mempermudah dalam pelayanan terhadap masyarakat yaitu terdiri Birokasi perizinan merupakan salah satu permasalahan yang menjadi kendala bagi perkembangan usaha di Indonesia. Kondisi pelayanan perizinan saat ini masih dihadapkan pada sistem yang belum efektif dan efisien serta belum sesuai dengan tuntutan masyarakat. J enis perizinan yang dilayani di Badan Pelayanan Pe- rizinan Terpadu Kota Bekasi yaitu 39 Perizinan. Salah satu ciri Negara maju adalah diterapkannya konsep dan prinsip-prinsip tata kelola pemerintahan yang baik dalam pelayanan publik, baik yang bersifat profit misalnya PDAM, listrik, telepon, transportasi, maupun yang non profit semacam STNK, SIM, KTP dan Paspor. Kedua jenis pelayanan publik ini seharusnya memperhatikan prinsip-prinsip dasar pelayanan publik yang baik yaitu adanya keterbukaan dalam hal informasi, kepastian waktu dan harga, serta keterjangkauannya. Selain itu juga harus diperhatikan faktor keadilan yaitu tidak diskriminatif. Kondisi pelayanan publik akan buruk apabila tidak adanya kesadaran masyarakat sendiri dan tidak adanya akses masyarakat untuk menyampaikan permasalahan-permasalahan yang ada. Pelayanan dalam artian luas adalah kegiatan yang dapat membuat pihak yang dilayani menjadi lebih mudah dan lebih nyaman dalam mendapatkan sesuatu yang boleh dalam arti kenyataannya pelayanan pemerintahan belum kooperatif dengan masyarakat. ${ }^{17}$ Sebelum adanya reformasi birokrasi perizinan dilakukan oleh beberapa dinas teknis di daerah seperti dinas perindustrian dan perdagangan mengeluarkan perizinan yang berkaitan dengan perizinan perdagaangan dan perindustrian yaitu surat izin usaha perdagangan (SIUP), surat izin usaha industri (SIUI), tanda Daftar Perusahaan (TDP), Tanda Daftar Gudang (TDG). Dinas bina marga yang mengeluarkan perizinan yang berkaitan dengan masalah pembangunan proyek rumah, jalan dan jembatan yaitu Surat Izin Usaha Jasa Konstruksi (SIUJ K). Izin Mendirikan Bangunan (IMB) instansi yang mengeluarkan adalah Dinas Tata Ruang dan Bangunan Kabupaten atau Kota. Surat Izin Usaha Pariwisata (SIUP) instansi yang mengeluarkan adalah Dinas Kebudayaan dan Pariwisata Kabupaten dan Kota.

Berdasarkan Peraturan Menteri Dalam Negeri Nomor 20 Tahun 2008 tentang Pedoman Organisasi dan Tata Kerja Unit Pelayanan Terpadu maka dibentuklah badan tersendiri yaitu

17 Elita Rahmi, Perizinan Dalam Pemerintahan (Sebuah Tantangan dan Harapan di Era Otonomi), Jurnal Hukum Respublica, Vol. 4 No.1 Tahun 2004, Pekanbaru: FH Universitas Lancang Kuning. hlm 122-130 
badan pelayanan perizinan terpadu yang mengeluarkan berbagai perizinan yang tadinya dikeluarkan oleh dinas-dinas secara terpisah maka dengan adanya badan sendiri yang bertugas mengeluarkan masalah perizinan. Dengan adanya badan pelayanan perizinan terpadu maka para pemohon perizinan cukup datang ke satu tempat maka semua perizinan dapat dimohonkan sehingga menghemat waktu dan kepastian biaya. Reformasi birokrasi mempunyai manfaat dalam proses pelayanan yang berorientasi pada kepuasan publik dan ketaatan aparatur birokasi terhadap peraturan perundang-undangan sehingga tidak terjadi penyimpangan dan perbuatan tercela. Hal ini sesuai dengan hasil dalam membangun reformasi birokasi yaitu: pertama, birokrasi yang bersih yang bekerja berdasarkan peraturan perundang-undangan yang berlaku dan nilai-nilai yang dapat mencegah berbagai tindakan penyimpangan dan perbutan tercela; kedua, birokrasi yang efisien, efektif dan orientasi pelanggan yaitu birokrasi yang dapat memberikan manfaat pada masyarakat dan menjalankan tugas dengan cermat dan berdaya guna; dan ketiga, birokrasi yang transparan yang membuka diri terhadap hak masyarakat untuk mendapatkan informasi tanpa diskriminasi. Sebelum adanya reformasi birokrasi perizinan dilakukan oleh beberapa dinas teknis di daerah seperti dinas perindustrian dan perdaganagan mengeluarkan perizinan yang berkaitan dengan perizinan perdagangan dan perindustrian yaitu surat izin usaha perdagangan (SIUP), surat izin usaha industri (SIUI), tanda Daftar Perusahaan (TDP), Tanda Daftar Gudang (TDG). Dinas Bina Marga yang mengeluarkan perizinan yang berkaitan dengan masalah pembangunan proyek rumah, jalan dan jembatan yaitu Surat Izin Usaha Jasa Konstruksi (SIUJ K). Izin Mendirikan Bangunan (IMB) instansi yang mengeluarkan adalah Dinas Tata Ruang dan Bangunan Kabupaten atau Kota. Surat Izin Usaha Pariwisata (SIUP) instansi yang mengeluarkan adalah Dinas Kebudayaan dan Pariwisata Kabupaten/ Kota.

Berdasarkan Peraturan Menteri Dalam Negeri Nomor 20 Tahun 2008 tentang Pedoman Organisasi dan Tata Kerja Unit Pelayanan Terpadu maka dibentuklah badan tersendiri yaitu badan pelayanan perizinan terpadu yang mengeluarkan berbagai perizinan yang tadinya dikeluarkan oleh dinas-dinas secara terpisah maka dengan adanya badan sendiri yang bertugas mengeluarkan masalah perizinan. Dengan adanya badan pelayanan perizinan terpadu maka para pemohon perizinan cukup datang ke satu tempat maka semua perizinan dapat dimohonkan sehingga menghemat waktu dan kepastian biaya. Reformasi birokrasi mempunyai manfaat dalam proses pelayanan yang berorientasi pada kepuasan publik dan ketaatan aparatur birokasi terhadap peraturan perundang-undangan sehingga tidak terjadi penyimpangan dan perbuatan tercela. Menurut pemikiran Weber suatu birokrasi modern mempunyai ciri-ciri sebagai berikut. Pertama, kegiatan birokrasi dilaksanakan secara teratur dengan batas-batas otoritas yang jelas; kedua, ada hirarki kewenangan; ketiga, ada aturan yang jelas tentang perilaku, otoritas dan tanggung jawab pegawai, dan keempat, pegawai diterima atas dasar merit bukan ikatan kekerabatan. Hambatan yang pertama adalah karena kurang tumbuhnya budaya pelayan publik dalam birokrasi kita, baik di pusat maupun di daerah. Kelangkaan budaya pelayanan publik ini muncul sebagai akibat adanya dualisme birokrasi dalam sistem administrasi kita. Kalau sistem ekonomi kita mengenal adanya dualisme antara ekonomi tradisional-agraris dan ekonomi modern industrial, maka dalam sistem administrasi kita dikenal adanya dualisme antara sistem administrasi tradisional yang menghasilkan ritualisme administratif yang tidak efisien dan sistem administrasi modern yang menekankan rasionalisme administratif yang efisien. Untuk merubah inkonsistensi tata nilai yang banyak di pengaruhi rituallisme adminstratif, sangat diperlukan program pendidikan dan pelatihan yang dirancang secara tepat. Hambatan yang kedua adalah karena kelemahan yang terkandung dalam sistem politik kita yang kurang mampu mengembangkan pengawasan oleh DPR dan DPRD. Salah satu sebab utama kekurang-berhasilan pembangunan di negara sosialis dan dunia ketiga menurut kajian yang diadakan oleh Institute of Development Studies, Universitas Sussex adalah karena le- 
mahnya sistem pengawasan demokratis di negara-negara ini. Sampai saat ini DPR dan DPRD, dengan berbagai cara, masih diperlakukan sebagai kepanjangan dari lembaga eksekutif, karena tidak ada kekuatan politik yang berarti yang mengontrol lembaga eksekutif.

Reformasi birokrasi mempunyai manfaat dalam proses pelayanan yang berorientasi pada kepuasan publik dan ketaatan aparatur birokasi terhadap peraturan perundang-undangan sehingga tidak terjadi penyimpangan dan perbuatan tercela. Hal ini sesuai dengan hasil dalam membangun reformasi birokasi yaitu: pertama, birokrasi yang bersih, yang bekerja berdasarkan peraturan perundang-undangan yang berlaku dan nilai-nilai yang dapat mencegah berbagai tindakan penyimpangan dan perbutan tercela; kedua, birokrasi yang efisien, efektif dan oerintasi pelanggan yaitu birokrasi yang dapat memberikan manfaat pada masyarakat dan menjalankan tugas dengan cermat dan berdaya guna; dan ketiga, birokrasi yang transparan yang membuka diri terhadap hak masyarakat untuk mendapatkan informasi tanpa diskriminasi.

\section{Pengaruh Reformasi Birokrasi terhadap Keter- bukaan Informasi}

Berdasarkan tujuan dari reformasi birokrasi adalah untuk membangun pemerintahan yang bersih, meningkatkan pelayanan publik, dan tersimpul dalam penyelenggaraan negara yang baik. Berdasarkan Presiden Nomor $03 \mathrm{Ta}$ hun 2006 tentang Paket Kebijakan Perbaikan Iklim Investasi, yang ditindak lanjuti oleh Peraturan Menteri Dalam Negeri Nomor 24 Tahun 2006 tentang Pedoman Penyelenggaraan Pelayanan Satu Pintu dan Peraturan Gubernur J awa Barat Nomor 29 Tahun 2007 tentang Perubahan Peraturan Penyelenggaraan Pelayanan Terpadu Satu Pintu maka daerah membentuk badan perizinan yang bersifat terpadu dan terpublikasi baik melalui papan pengumuman, brosur-brosur, pusat informasi dan website lembaga mengenai prosedur, persyaratan, waktu dan biaya yang dibutuhkan dalam proses perizinan sehingga lemba-ga yang berfungsi untuk melaya- ni proses perizinan khususnya berkaitan dengan perizinan penanaman modal.

Upaya meningkatkan pelayanan pubik kepada masyarakat yang baik sesuai dengan asasasas umum dan prinsip-prinsip tata kelola pemerintahan yang baik khususanya asas keterbukaan yaitu yang melayani masyarakat untuk memperoleh informasi yang benar, jujur, dan tidak diskriminatif dalam penyelenggaraan administrasi pemerintahan dengan tetap memperhatikan perlindungan atas hak pribadi, golongan, dan rahasia negara dan prinsip transparansi perlu dibangun berdasarkan arus informasi yang bebas. Seluruh proses pemerintahan, lembagalembaga dan informasi perlu dapat diakses oleh pihak-pihak yang berkepentingan, dan informasi yang tersedia harus memadai agar dapat dimengerti dan dipantau maka pemerintahan daerah membentuk masing-masing badan yang melayani perizinan yang bersifat terpadu yaitu Pemerintahan Kota Bekasi berdasarkan Peraturan Daerah Kota Bekasi Nomor 35 Tahun 2008 tentang Penbentukan Badan Pelayanan Perizinan Terpadu Kota Bekasi. Badan Pelayanan Perizinan Terpadu Kota Bekasi saat ini melayani 39 jenis perizinan.

Pelaksanaan reformasi birokrasi di sektor penanaman modal, badan atau lembaga yang bertugas menjalankan reformasi birokrasi mempunyai hambatan-hambatan yang berkaitan dengan pelayanan yang bersifat langsung maupun tidak langsung. Adapun hambatan-hambatannya antara lain yaitu belum sinkronnya pemahaman Peraturan daerah dan Peraturan bupati tentang perizinan, sehingga dinas terkait belum sepenuh hati menyerahkan pengelolaan perizinan ke Badan Pelayanan Perizinan Terpadu karena dinas-dinas tersebut merasa kehilangan lahan garapan; belum adanya sekretariat bersama, sehingga pelaksanaan terpadu satu pintu belum berjalan secara optimal; belum meratanya kemampuan para pegawai Badan pelayanan Perizinan Terpadu mengenai penyelenggaraan pelayanaan perizinan, sehingga perlu diadakan diklat-diklat meningkatkan sumber daya manusia di Badan Pelayanan Perizinan Terpadu; kurang mencukupi biaya operasional yang di anggarkan oleh Anggaran Pendapatan Belanja Dae- 
rah, sehingga tidak adanya dukungan biaya sosialisai dan operasional bagi petugas lapangan, baik untuk kegiatan survey, dan lain-lain yang menyebabkan beban biaya ekonomi tinggi kepada para pengusaha; kurangnya sarana prasarana yaitu berupa kendaraan operasional dalam melakukan kegiatan survey, dan lain-lain yang menyebabkan waktu proses pelayanan menjadi lebih lama serta kurangnya lahan parkir dan gudang arsip yang masih terbatas daya tampungnya sehingga menggangu proses dan kenyamanan pemohon perizinan. Belum adanya Penyidik Pegawai Negeri Sipil (PPNS) perizinan, sehingga dengan tidak adanya Penyidik Pegawai Negeri Sipil (PPNS) pada Badan Pelayanan Perizinan Terpadu (BPPT) akan menyulitkan tingkat penyelesaian permasalahan hukum terkait dengan penyimpangan-penyimpangan oleh para pengusaha.

Keterbukaan merupakan salah satu asas pemerintahan yang baik terdapat dalam Pasal 3 ayat 3 Undang-Undang Nomor 28 tahun 1999 tentang Penyelenggaraan Yang Bersih dan Bebas dari Korupsi, Kolusi dan Nepotisme. Keterbukaan atau transparansi berasal dari kata dasar terbuka dan transparan, yang secara harfiah berarti jernih, tembus cahaya, nyata, jelas, mudah dipahami, tidak keliru, tidak sangsi atau tidak ada keraguan. Dengan demikian Keterbukaan atau transparansi adalah tindakan yang memungkinkan suatu persoalan menjadi jelas mudah dipahami dan tidak disangsikan lagi kebenarannya. Kaitannya dengan penyelenggaraan pemerintahan, keterbukaan atau transparansi berarti kesediaan pemerintah untuk senantiasa memberikan informasi faktual mengenai berbagai hal yang berkenaan dengan proses penyelenggaraan pemerintahan.

Makna keterbukaan dalam kehidupan berbangsa dan bernegara, dalam teori demokrasi pemerintahan yang terbuka adalah suatu hal yang esensial atau penting terutama akses bebas setiap warga negara terhadap berbagai sumber informasi, supaya tidak terjadi saling curiga antar individu, masyarakat dengan pemerintah. Keterbukaan dalam penyelenggaraan yaitu setiap kebijakan haruslah jelas, tidak dilakukan secara sembunyi, rahasia tetapi peren- canaan, pelaksanaan, pertanggungjawabannya bisa diketahui publik dan rakyat berhak atas informasi faktual mengenai berbagai hal yang menyangkut pembuatan dan penerapan kebijakan. Ada 3 alasan pentingnya keterbukaan dalam penyelenggaraan pemerintahan di sektor pelayanan publik. Kekuasaan pada dasarnya cenderung diselewengkan. Semakin besar kekuasaan semakin besar pula kemungkinan terjadi penyelewengan. Dasar penyelenggaraan pemerintahan itu dari rakyat, oleh rakyat, dan untuk rakyat, agar penyelenggaraan pemerintahan itu tetap dijalur yang benar untuk kesejahteraan rakyat. Dengan keterbukaan memungkinkan adanya akses bebas warga negara terhadap informasi yang pada gilirannya akan memiliki pemahaman yang jernih sehingga mampu berpartisipasi aktif dalam menciptakan pemerintahan yang konstruktif dan rasional.

Prinsip mengenai pemerintahan yang terbuka tidak berarti bahwa semua informasi mengenai penyelenggaraan boleh diakses oleh publik. Ada informasi tertentu yang tidak boleh diketahui oleh umum berdasarkan undang-undang. Ada beberapa ciri keterbukaan menurut David Beetham dan Kevin Boyle. Pertama, Pemerintah menyediakan berbagai informasi faktual mengenai kebijakan yang akan dan sudah dibuatnya; kedua, adanya peluang bagi publik dan pers untuk mendapatkan atau mengakses berbagai dokumen pemerintah melalui parlemen; ketiga, terbukanya rapat-rapat pemerintah bagi publik dan pers, termasuk rapat-rapat parlemen; dan keempat, adanya konsultasi publik yang dilakukan secara sistematik oleh pemerintah mengenai berbagai kepentingan yang berkaitan dengan perumusan dan pelaksanaan kebijakan. Menurut David Beetham dan Kevin Boyle ada 4 hal informasi yang tidak boleh diketahui publik. Pertama, pertimbanganpertimbangan kabinet; kedua, nasehat politis yang diberikan kepada menteri; ketiga, informasi-informasi yang menyangkut pertahanan nasional, kelangsungan hidup demokrasi dan keselamatan individu, warga masyarakat; keempat, rahasia perdagangan dari perusahaan swasta. Standar pelayanan pubik setiap unit pelayanan instansi pemerintahan wajib menyu- 
sun standar pelayanan masing-masing sesuai tugas dan wewenangnya dan dipublikasikan kepada masyarakat sebagai jaminan adanya kepastian bagi penerimaan pelayanan. Standar pelayanan merupakan ukuran kualitas kinerja yang dibakukan dalam penyelenggaraan pelayanan publik yang wajib ditaati oleh pemberi dan atau penerima pelayanan. Standar pelayanan yang ditetapkan hendaknya realistis karena merupakan jaminan bahwa janji atau komitmen yang dibuat dapat dipenuhi, jelas dan mudah dimengerti oleh para pemberi dan penerima pelayanan. Informasi pelayanan, untuk memenuhi kebutuhan informasi pelayanan kepada masyarakat, setiap unit pelayanan instansi pemerintah wajib mem-publikasikan mengenai prosedur, persyaratan, biaya, waktu, standar, akta/janji, sebagaimana telah diuraikan di atas. Publikasi dan atau sosialisasi tersebut di atas melalui antara lain, media cetak (brosur, leaflet, booklet) media elektronik (Website, Home Page, Situs Internet, radio, TV), media gambar, dan/atau penyuluhan secara langsung kepada masyarakat. ${ }^{18}$

Menurut pendapat Dadang Solihin dalam penerapan prinsip-prinsip tata kelola pemerintahan yang baik dalam pembangunan daerah di perlukan suatu pendekatan mempunyai parameter atau ukuran yang tergambar dalam indikator minimal dan perangkat pendukung indikator. Indikator minimal dari parameter atau ukuran berjalannya proses asas keterbukaan dan transparansi adalah: ${ }^{19}$ pertama, tersedianya informasi yang memadai pada setiap proses penyusunan dan implementasi kebijakan publik kedua, adanya akses pada informasi yang siap, mudah dijangkau, bebas diperoleh, dan tepat waktu. Perangkat pendukung indikator tersebut adalah: peraturan yang menjamin hak untuk mendapatkan informasi; pusat/balai in-

18 Teni Listiani, “Implementasi Kebijakan Transparansi dan Akuntabilitas Pelayanan Publik (Studi di PDAM Kota Bandung)", J urnal IImu Administrasi, Vol. IV No. 3 September 2007, Bandung: Sekolah Tinggi IImu Adminitrasi LAN. hlm. 303-318

19 Dadang Solihin, "Penerapan Prinsip-Prinsip Good Governance dalam Pembangunan Daerah", 16 Januari 2006, tersedia diwebsite http://www.slideshare.net/ DadangSolihin/ penerapan-prinsipprinsip-good-governance-dalam-pembangunan-daerah, diakses tanggal 22 Februari 2012 formasi; website (e-government, e-procurement, dan sebagainya); iklan layanan masyarakat; media cetak dan elektronik; papan pengumuman; dan pameran pembangunan.

Berdasarkan penjelasan diatas mengenai pengertian dan indikator tentang asas-asas umum dan tata kelola pemerintahan yang baik khususnya asas keterbukaan dan transparansi maka pemerintahan kota bekasi melalui media papan pengumuman, brosur, pusat informasi dan website lembaga memberikan informasi yang berkaitan dengan proses perizinan seperti prosedur, persyaratan, waktu dan biaya perizinan. Pemerintah daerah melaksanakan tujuan reformasi birokrasi untuk melakukan reformasi di kelembagaan yaitu dengan membentuk lembaga baru yang secara khusus menangani perizinan, mereformasi ketatalaksanaan dengan membuat standar prosedur yang baku dan melakukan pengembangan sumber daya manusia dengan memberikan diklat secara bertahap sesuai dengan kemampuan keuangan daerah. Reformasi birokrasi mempunyai manfaat dalam proses pelayanan yang berorientasi pada kepuasan publik dan ketaatan aparatur birokasi terhadap peraturan perundang-undangan sehingga tidak terjadi penyimpangan dan perbuatan tercela. Hal ini sesuai dengan hasil dalam membangun reformasi birokasi yaitu: pertama, birokrasi yang bersih yang bekerja berdasarkan peraturan perundang-undangan yang berlaku dan nilai-nilai yang dapat mencegah berbagai tindakan penyimpangan dan perbutan tercela; kedua, birokrasi yang efisien, efektif dan orientasi pelanggan yaitu birokrasi yang dapat memberikan manfaat pada masyarakat dan menjalankan tugas dengan cermat dan berdaya guna; dan ketiga, birokrasi yang transparan yang membuka diri terhadap hak masyarakat untuk mendapatkan informasi tanpa diskriminasi dan menerima kritik.

Sebelum adanya reformasi birokrasi perizinan penanaman modal dilakukan oleh beberapa dinas teknis di daerah seperti dinas perindustrian dan perdagangan mengeluarkan perizinan yang berkaitan dengan perizinan perdagaangan dan perindustrian yaitu surat izin usaha perdagangan (SIUP), surat izin usaha in- 
dustri (SIUI), tanda Daftar Perusahaan (TDP), Tanda Daftar Gudang (TDG). Dinas Bina Marga yang megeluarkan perizinan yang berkaitan dengan masalah pembangunan proyek rumah, jaIan dan jembatan yaitu Surat Izin Usaha Jasa Konstruksi (SIUJ K). Izin Mendirikan Bangunan (IMB) instansi yang mengeluarkan adalah Dinas Tata Ruang dan Bangunan Kabupaten atau Kota. Surat Izin Usaha Pariwisata (SIUP) instansi yang mengeluarkan adalah Dinas Kebudayaan dan Pariwisata Kabupaten dan Kota. Reformasi birokrasi memberikan manfaat pada masyarakat berupa: pertama, proses pelayanan dilakukan hanya di satu tempat itu mempermudah dan menghemat waktu, kedua, persyaratan dan prosedur pengajuan mudah diakes dengan adanya publikasi melalui media brosur, papan pengumuman, pu-sat informasi dan website instansi perizinan, dan ketiga, secara tidak langsung masyarakat mendapatkan manfaat dengan mudahnya perizinan maka pengusaha membuka lapangan kerja karena proses penanaman modal berjalan dengan baik.

Berdasarkan Peraturan Menteri dalam Negeri Nomor 20 Tahun 2008 tentang Pedoman Organisasi dan Tata Kerja Unit Pelayanan Terpadu maka dibentuklah badan tersendiri yaitu Badan Pelayanan Perizinan Terpadu Satu Atap yang mengeluarkan berbagai perizinan yang tadinya dikeluarkan oleh dinas-dinas secara terpisah maka dengan adanya badan sendiri yang bertugas mengeluarkan masalah perizinan. Dengan adanya badan pelayanan perizinan terpadu maka para pemohon perizinan cukup datang ke satu tempat maka semua perizinan dapat dimohonkan sehingga menghemat waktu dan adanya kepastian biaya. Reformasi birokrasi mempunyai manfaat dalam proses pelayanan yang berorientasi pada kepuasan publik dan ketaatan aparatur birokasi terhadap peraturan perundang-undangan sehingga tidak terjadi penyimpangan dan perbuatan tercela. Hal ini sesuai dengan hasil yang diharapkan dalam membangun reformasi birokasi yaitu: pertama, birokasi yang bersih yang bekerja berdasarkan peraturan perundang-undangan yang berlaku dan nilai-nilai yang dapat mencegah berbagai tindakan penyimpangan dan perbutan tercela; ke- dua, birokrasi yang efisien, efektif dan orientasi pelanggan yaitu birokrasi yang dapat memberikan manfaat pada masyarakat dan menjalankan tugas dengan cermat dan berdaya guna; dan ketiga, birokrasi yang transparan yang membuka diri terhadap hak masyarakat untuk mendapatkan informasi tanpa diskriminasi.

\section{Penutup \\ Simpulan}

Reformasi birokrasi perizinan dimulai berdasarkan Peraturan Presiden Nomor 03 Tahun 2006 tentang Paket Kebijakan Perbaikan Iklim Investasi, dan ditindak Ianjuti oleh Peraturan Menteri Dalam Negeri Nomor 24 Tahun 2006 tentang Pedoman Penyelenggaraan Pelayanan Satu Pintu dan Peraturan Gubernur J awa Barat Nomor. 29 Tahun 2008 tentang Perubahan Peraturan Penyelenggaraan Pelayanan Terpadu Satu Pintu maka Kota Bekasi berdasarkan Peraturan Daerah Kota Bekasi Nomor. 35 Tahun 2008 tentang Penbentukan Badan Pelayanan Perizinan Terpadu Kota Bekasi. Badan Pelayanan Perizinan Terpadu Kota Bekasi saat ini melayani 39 jenis perizinan. Pengaruh reformasi birokrasi yang nyata yaitu mempersingkat waktu karena semua proses perizinan penanaman modal dilakukan di satu tempat yaitu Badan Pelayanan Perizinan Terpadu Kota Bekasi, berbeda dengan sebelum reformasi birokrasi, perizinan harus dilakukan di banyak instansi. Keterbukaan informasi berjalan seperti persyaratan dan prosedur mudah di akses dengan dipublikasi melalui media brosur, papan pengumuman, pusat informasi dan website instansi.

\section{Saran}

Ada beberapa saran yang dapat diberikan berkaitan dengan permasalahan yang dibahas. Pertama, melakukan dan memaksimalkan sosialisasi tentang adanya lembaga perizinan terpadu satu atap di kota atau kabupaten setempat, sehingga masyarakat pada umumnya dan pengusaha khususnya mengetahui mengenai prosedur, persyaratan, biaya dan waktu yang di butuhkan dalam proses mendapatkan suatu perizinan. Kedua, meningkatkan sarana prasarana yaitu berupa kendaraan operasional untuk me- 
lakukan kegiatan survey, dan lain-lain sehingga meningkatkan waktu proses pelayanan menjadi lebih cepat serta menambah lahan parkir dan gudang arsip sehingga menambah daya tampung, sehingga dalam melakukan proses permohonan perizinan menjadi lebih nyaman dan aman. Ketiga, diadakan Penyidik Pegawai Negeri Sipil (PPNS) perizinan, sehingga dengan adanya Penyidik Pegawai Negeri Sipil (PPNS) pada Badan Pelayanan Perizinan Terpadu (BPPT) akan mempermudah penyelesaian permasalahan hukum terkait dengan penyimpangan-penyimpangan oleh para pengusaha. Keempat, dilakukan diklat-diklat secara teratur untuk meningkatkan sumber daya manusia di Badan Pelayanan Perizinan Terpadu sehingga dengan meningkatnya kemampuan para pegawai $\mathrm{Ba}$ dan pelayanan Perizinan Terpadu mengenai penyelenggaraan pelayanaan perizinan diharapkan pelayanan menjadi lebih baik.

\section{Daftar Pustaka}

Delfitri, Yefni. 2005. Reformasi Birokrasi di Mahkamah Agung. Jakarta: Universitas Krisnadwipayana;

Helmi. "Membangun Sistem Perizinan Terpadu Bidang Lingkugan Hidup di Indonesia". Jurnal Dinamika Hukum, Vol. 11 No.1 Edisi J anuari 2011. Purwokerto: Fakultas Hukum UNSOED;

Jailani. “Urgensi Nilai-Nilai Akhlaq Pada Birokrasi Pemerintahan dalam Pelayanan Publik". Jurnal Al-Bayan, Vol. 12 No. 13 Edisi J anuari-J uni 2006. Nanggroe Aceh Darussalam: Fakultas Dakwah Institut Agama Islam Negri Ar-Rainy;

Kurniasih, Denok dan Anwaruddin. "Reformasi Birokrasi Pelayanan Perizinan di Kabupaten Banyumas (Studi di Kantor Pelayanan Perizinan dan Investasi)". Jurnal Humanis, Vol. I No. 2 Edisi Nopember 2007 April 2008. Purwokerto: LPPM UNSOED;

Listiani, Teni. "Implementasi Kebijakan Transparansi dan Akuntabilitas Pelayanan Publik (Studi di PDAM Kota Bandung)". Jurnal IImu Administrasi, Vol. IV No. 3
Edisi September 2007. Manado: IImu Administrasi Universitas Sam Ratulangi;

Nawawi, Zaidan. "Kinerja Pelayanan Publik". J urnal Eksekutif, Vol. 4 No. 2 Edisi Agustus 2007. Surabaya: Sekolah Tinggi IImu Ekonomi IBMT;

Rahmi, Elita. "Perizinan dalam Pemerintahan (Sebuah Tantangan dan Harapan di Era Otonomi)". Jurnal Hukum Respublica, Vol. 4 No.1 Tahun 2004. Pekanbaru: FH Universitas Lancang Kuning;

Saleh, Asri M. "Arti Penting Kehadiran Ombudsman Bagi Masyarakat Di Provinsi Riau". J urnal Hukum Respublica, Vol. 3 No. 2 Tahun 2004. Pekanbaru: FH Universitas Lancang Kuning;

Sinamo, Nomensen. $2010 . \quad$ Hukum Administrasi Negara. Jakarta : PT.Jala Permata Aksara;

Soeprapto, Riyadi. "Pengembangan Model Citizen Charter dalam Meningkatkan Pelayanan Publik Di Indonesia". Delegasi, No. 2 Edisi Agustus 2005. Banjarmasin: LPPM Sekolah Tinggi Ilmu Adminitrasi;

Solihin, Dadang. 16 Januari 2006. "Penerapan Prinsip-Prinsip Good Governance dalam Pembangunan Daerah", tersedia diwebsite http: // www. slideshare.net/Dadang Solihin / penerapan-prinsip-prinsip-goodgovernance-dalam-pembangunan-daerah, diakses tanggal 22 Februari 2012;

Suhendar, Ade. "Keterbukaan Informasi Publik Bentuk Keseriusan Pemerintah Menuju Good Governance (Implementasi UU No. 14 Tahun 2008)". Jurnal Wacana Kerja, Vol. 13 No.2 edisi November 2010. Bandung: Pusat Kajian dan Pendidikan dan Peneletian Aparatur;

Sulaiman, T Nazarudin. "LandasanTeoritik Pelayanan Perizinan Terpadu Satu Pintu". Suloh: Jurnal Penelitian dan Pengkajian Hukum, Vol. 6 No. Edisi Khusus 2008;

Sutji, Asmara Budi Dyah Dharma. "Ombudsman di Indonesia". Jurnal Hukum dan Masyarakat, Vol. 33 No. 1 Tahun 2008;

Thontowi, Jawahir. "Norma Hukum Pelayanan Publik". J urnal Hukum, Vol. 14 No.3 Edisi April 2004. Yogyakarta: FH Universitas Islam Indonesia. 